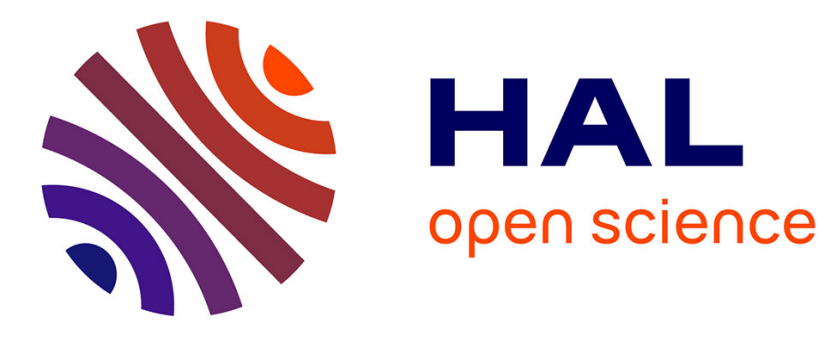

\title{
High prevalence of Hepatitis E virus in French domestic pigs
}

\author{
Nicolas Rose, Aurélie Lunazzi, Virginie Dorenlor, Thiziri Merbah, Florent \\ Eono, Marc Eloit, François Madec, Nicole Pavio
}

\section{- To cite this version:}

Nicolas Rose, Aurélie Lunazzi, Virginie Dorenlor, Thiziri Merbah, Florent Eono, et al.. High prevalence of Hepatitis E virus in French domestic pigs. Comparative Immunology, Microbiology and Infectious Diseases, 2011, pp.419-427. 10.1016/j.cimid.2011.07.003 . hal-01191111

\section{HAL Id: hal-01191111 \\ https://hal.science/hal-01191111}

Submitted on 1 Sep 2015

HAL is a multi-disciplinary open access archive for the deposit and dissemination of scientific research documents, whether they are published or not. The documents may come from teaching and research institutions in France or abroad, or from public or private research centers.
L'archive ouverte pluridisciplinaire HAL, est destinée au dépôt et à la diffusion de documents scientifiques de niveau recherche, publiés ou non, émanant des établissements d'enseignement et de recherche français ou étrangers, des laboratoires publics ou privés. 


\title{
Comparative Immunology, Microbiology and Infectious Diseases
}

\section{High prevalence of Hepatitis E virus in French domestic pigs}

\author{
Nicolas Rose ${ }^{\mathrm{a}, *}$, Aurélie Lunazzi ${ }^{\mathrm{b}}$, Virginie Dorenlor ${ }^{\mathrm{a}}$, Thiziri Merbah ${ }^{\mathrm{b}}$, Florent Eono ${ }^{\mathrm{a}}$, \\ Marc Eloit ${ }^{c}$, François Madec ${ }^{\mathrm{a}}$, Nicole Pavio ${ }^{\mathrm{b}}$ \\ a Anses, Laboratoire de Ploufragan/Plouzané, BP53, 22440 Ploufragan, France \\ b Anses, Laboratoire de santé animale, ENVA, INRA, 23 Avenue du General de Gaulle 94706 Maisons-Alfort, France \\ c Anses, ENVA, INRA, Ecole Nationale Vétérinaire d'Alfort, 7 Avenue du General de Gaulle 94704 Maisons-Alfort, France
}

\section{A R T I C L E I N F O}

\section{Article history:}

Received 27 May 2011

Received in revised form 28 July 2011

Accepted 29 July 2011

\section{Keywords:}

Hepatitis E

Pig

Animal reservoir

Zoonosis

Public health

\begin{abstract}
A B S T R A C T
The importance of the domestic pig reservoir for Hepatitis E virus (HEV) was assessed by estimating the seroprevalence and prevalence of HEV contaminated livers in French slaughter-aged pigs. 6565 sera and 3715 livers were randomly sampled from 186 pig farms throughout the country. Taking the sampling design into account, the farm-level seroprevalence was $65 \%$ (95\% CI 57-74) and 31\% (95\% CI 24-38) of the slaughter-aged pigs had antibodies against HEV. The individual prevalence of HEV RNA positive livers was $4 \%$ (95\% CI 2-6) and $24 \%$ (95\% CI 17-31) of the farms had at least 1 positive liver. Most isolates were of genotype $3 f(76.7 \%)$ with smaller amounts of $3 c(18.6 \%)$ and $3 e(4.6 \%)$. The high prevalence of HEV in pigs and the similarities between HEV subtypes from pigs and humans corroborates the possible zoonotic origin of some HEV autochthonous infections.

(c) 2011 Elsevier Ltd. All rights reserved.
\end{abstract}

\section{Introduction}

Hepatitis E virus is a non-enveloped, positive sense, single stranded RNA virus of approximately 7.2 kilobases and sole member of the Hepevirus genus in the Hepeviridae family [1]. In humans, it is responsible for an acute enterically-transmitted hepatitis similar to Hepatitis A. Some cases can be very severe and lead to fulminant hepatitis (1-2\% of the cases). Hepatitis $E$ is mostly selflimiting and generally does not progress to chronicity [2,3] although several chronic cases have been reported $[4,5]$ in patients under immunosuppressive treatment, who may develop cirrhosis [5]. The four main genotypes of HEV [3] show a distinct geographical distribution. Genotypes 1 and 2 are exclusively recovered from humans as sporadic cases or large outbreaks in Asian and African countries and also in Mexico for genotype 2, whereas genotypes 3 and 4 are shared between humans and animals. These latter

\footnotetext{
* Corresponding author. Tel.: +33 296016 441; fax: +33296016295 E-mail address: nicolas.rose@anses.fr (N. Rose).
}

genotypes are commonly associated with locally-acquired Hepatitis E cases in North America, Europe, Japan and China for genotype 3, and Japan, China and Taiwan for genotype 4.

In France, the number of locally-acquired Hepatitis E cases reported to the national reference centre increased between 2002 ( 9 cases) and 2009 (184 cases) while the number of imported cases remained stable [6,7].

In most cases the origin of autochthonous Hepatitis $\mathrm{E}$ is unknown, but foodborne infection was clearly established in two cases where HEV transmission followed the consumption of raw deer meat [8] or undercooked wild boar meat [9]. In France, some sporadic cases, and also foodborne outbreaks, were reported between 2008 and 2009 , and the consumption of raw pig liver sausages was strongly suspected as the source of infection [10]. However this evidence of foodborne sources is relatively sparse and not always linked directly with the locally-acquired cases reported annually in France. For some cases, the National Reference Centre questionnaires cited a frequent consumption of raw salted pork meat and the consumption of water from a private source [6]. In Germany a case-control study 
identified the consumption of wild boar meat and offal as risk factors for Hepatitis E infection in humans [11]. In the United States, the reported HEV prevalence in a large seroprevalence study was $21.0 \%$ and having a pet in the home and consuming liver or other organ meats were significantly associated with increased odds of HEV seropositivity [12].

Serological studies in France evidenced significant differences according to geographical location. The prevalence of anti-HEV IgG in blood donors was $16.4 \%$ in southwest France [13] compared to $3.2 \%$ in the regions Ile de France and Pays de la Loire which are in northwest France [14]. Furthermore, a national survey has shown an increasing North-to-South gradient of acute Hepatitis E [15] in agreement with a more frequent HEV exposure in southern France. These differences according to geographical area have not been clearly explained but might be related to a more frequent consumption of raw pig liverbased products in the South of France [10].

Hepatitis E virus is widespread in the domestic pig population. Serological studies carried out in many countries showed a high prevalence at the farm level [16-20] with large variations at the individual level [16,21-23] and also between studies according to geographical location and the serological tests used. A few data are also available for viremia and virus presence in slaughter-aged pigs. The prevalence of liver contamination in samples collected in grocery stores was $11.2 \%$ in the US [24] and $6.5 \%$ in the Netherlands [25]. However, those figures were obtained from a relatively small sample.

In the United States and Sweden, studies of HEV prevalence in pig handlers and veterinary workers revealed a higher than normal antibody prevalence in these populations $[26,27]$. Swine veterinarians in the US study were 1.5 times (95\% CI: 1.03-2.20) more at risk of being HEV seropositive than normal blood donors in the matched control population. Thus, frequent contacts with pigs might increase the probability of HEV infection through exposure to contaminated materials.

The aim of the present study was therefore to quantitatively assess the importance of the domestic pig population in France as a potential reservoir for Hepatitis E virus. A nationwide prevalence survey was carried out to determine (i) HEV seroprevalence at the farm- and pig-levels, (ii) the prevalence of HEV in pig livers at slaughter and (iii) the HEV subtypes circulating in pig population.

\section{Materials and methods}

\subsection{Sampling description}

Data from the literature, in which the observed farmlevel prevalence was high, were used to determine the total number of herds to sample. Previous data obtained from a limited number of slaughterhouses in France had indicated a farm-level prevalence close to $70 \%$ [28] which is consistent with data from other countries. The number of herds required to estimate $70 \%$ with $10 \%$ relative precision and $95 \%$ confidence, was 165 . This number was increased to 186 to allow for uncontrolled events. The observed minimum within-herd prevalence in this same study was close to $10 \%$ and this value was retained as the minimum withinherd target prevalence to be detected. Given the expected $50 \%$ sensitivity and $98 \%$ specificity of the commercial serological tests [28], this led to sampling of 30 pigs in flocks with less than 50 pigs, 40 pigs in flocks of 50-100 pigs and 50 pigs in flocks with more than 100 pigs, with a confidence level of $95 \%$. Given the total number of herds to be sampled, serological results from more than 5500 pigs were therefore expected. Taking into account the multistage cluster design (sampled pigs as primary sampling units are nested within herds and within slaughterhouses) this would allow an expected individual prevalence of $50 \%$ to be determined with $5 \%$ relative precision. The number of livers to be sampled per herd was fixed at 20 whatever the herd size. This sample size would lead to the analysis of 3700 livers and thus determination of an expected $11 \%$ individual prevalence with a relative precision of $20 \%$, taking into account the multistage cluster design.

The herds to be sampled were determined by random selection of a list of slaughter dates and times from a database table. This database was constituted by compiling all possible slaughter date and time from May 1st 2008 to November 30th 2009 for the 35 selected slaughterhouses (which represented more than $95 \%$ of the national production according to a preliminary census survey in French slaughterhouses). The number of herds to be sampled per slaughterhouse was determined from the number of pigs slaughtered/year and taking a minimum of 4 herds/slaughterhouse. The SURVEYSELECT procedure (SAS 9.1) was used to randomly define the list of dates and times to take the herd, according to the number required per slaughterhouse and stratifying according to season.

\subsection{Biological samples}

The herds to sample were chosen according to the randomly selected date and time. Care was taken that pigs from a selected herd were not mingled with others from a different herd. Blood samples were taken at the bleeding post. To minimize cross-contamination of samples at the bleeding post, empty blood collection tubes without any additive were kept by an operator in a test tube rack, holding them apart from the bleeding post. Empty tubes were given to the second operator for each pig separately to be filled in just after exsanguination. The filled tube was immediately corked and stored in a separate bag before a new one was filled again. Each sampled pig was identified with an ear tag to ensure that livers were sampled from matched carcasses. Small sections $(2 \mathrm{~cm} \times 1 \mathrm{~cm} \times 1 \mathrm{~cm})$ were cut from the area immediately above the gall-bladder (left medial lobe) of selected livers changing gloves and blades between each liver to prevent from cross-contamination from one liver to another. These samples were immediately placed at $4{ }^{\circ} \mathrm{C}$, frozen and then stored at $-80^{\circ} \mathrm{C}$ until analysis.

\subsection{Serological analysis}

Serum samples collected at the slaughterhouse were tested with the Anti-HEV total immunoglobulin for Human diagnosis EIAgen HEV Ab Kit ${ }^{\circledR}$ Adaltis (Ingen, France). All 
the manufacturer's instructions were followed, except that the secondary antibody was replaced by a peroxidaseconjugated rabbit polyclonal anti-pig IgG $(\mathrm{H}+\mathrm{L})$ (Abcam, France) diluted 1:8000 in the dilution buffer IDVet3 which is used for the dilution of secondary antibodies conjugated to peroxidase in ELISA test (IDVet, Montpellier, France). For data analysis, the cut-off value (Co) was calculated as the mean optical density (OD450 nm) value of the negative control $(\mathrm{NC})+0.350$. The experiment was validated with a value of $\mathrm{NC}$ - blank control (reagents only) $<0.05$. Results were interpreted as the ratio of sample (S) OD450 nm to the cut-off value (or S/Co) as follows: $\mathrm{S} / \mathrm{Co}<1.1=$ negative $\mathrm{S} / \mathrm{Co}>1.1=$ positive. Each sample was subjected to monocupule analysis. The negative control is a serum obtained from a Specific Pathogen Free pig from the Level 3 animal facility at the Anses Laboratory in Ploufragan (France) [29]. The positive control is a pool of positive swine sera identified positive in a previous study on evaluating the performance of a virus-like particles-based ELISA for serology of HEV in swine and the Elisa test used in the present study [28].

\subsection{Molecular detection of HEV}

RNA was extracted from liver samples using the RNeasy Mini Kit (Qiagen, France) according to the manufacturer's instructions. Thirty milligrams of liver tissues were homogenized in lysis buffer (RNeasy Mini Kit, Qiagen, France) using the Fast Prep 24 System (MP Biomedicals, France) in Lysis matrix D tubes (MP Biomedicals, France). After eluting the RNA in water, RT-nested PCR was performed on five microliters according to the protocol described by Cooper and collaborators [17]. The amplified fragment of 348 nucleotides is located in the $5^{\prime}$ region of the HEV ORF-2. To avoid contaminations with the sensitive nested RT-PCR method used, samples were analyzed following the Good Laboratory Practice and the unidirectional workflow in 4 separate rooms. In addition, all PCR products were sequenced and different HEV strains were identified in each herd confirming the absence of cross contamination [30]. Repeatability of HEV RNA isolation was assessed by independent analysis (extraction and molecular detection) of 140 liver samples from 7 herds. The same results (positive and negative samples) were obtained in both experiments (data not shown). Then, liver samples were analyzed in single detection and positive samples were confirmed using the real-time RT-PCR procedure published by Jothikumar and collaborators [31] (data not shown). To control the extraction and detection procedures, a positive liver sample from an HEV experimentally infected swine, with a genotype 3 HEV (Genbank accession number EF494700), was run simultaneously with every series of 20 liver samples from the same herd. Negative controls (Reverse transcription, first PCR and nested PCR) were included in every series. The presence of RT-PCR inhibitor was investigated per series of 20 samples, by adding HEV RNA extracted from a positive liver from an experimentally-infected pig to one of the newly extracted sample. Positive samples were dispatched for sequencing to Eurofins MWG Operon (Ebersberg, Germany).

For each positive liver sample, molecular detection of HEV was performed on the corresponding sera. RNA extraction was performed on two hundred microliters of serum using the Qiamp Viral RNA extraction Kit (Qiagen, France). HEV amplification was performed on $5 \mu$ l according to the protocol described by Cooper and collaborators [17]. Negative and positive (serum from an experimentally-infected pig or negative control) controls (reverse transcription, first PCR and nested PCR) were included in each experiment.

\subsection{Statistical analysis}

The design of the survey (multistage cluster sampling, unequal weighting of observations) was taken into account in determining the seroprevalence of fattening pigs and the prevalence of HEV contaminated livers. The sampling rate was calculated for each slaughterhouse using previously collected data on number of pigs slaughtered/year/slaughterhouse updated for years 2008 and 2009. The Taylor expansion method provided in Proc SURVEYFREQ [32] was used to estimate the sampling error of estimators based on complex sample designs [33,34]. For the seroprevalence results, the individual sensitivity (Se) and specificity (Sp) of the test estimated previously [28] was used to correct the estimate at the individual level. The herd-level seroprevalence estimate was also corrected by calculating values for herd-sensitivity (HSe) and herdspecificity (HSp) as defined in Dohoo et al. [35].

The influence of season, geographical region, type of herd and relationships between serological and virological results were assessed by logistic regression, taking into account the survey design and unequal weighting of observations with the SURVEYLOGISTIC procedure [32].

Table 1

Seroprevalence and HEV prevalence estimates from the National prevalence study (186 farms, 6565 blood samples, 3715 livers, France, 2008-2009).

\begin{tabular}{|c|c|c|c|c|c|}
\hline & Sample size & $\begin{array}{l}\text { Number } \\
\text { positive }\end{array}$ & $\begin{array}{l}\text { Prevalence } \\
\text { estimate (\%) }\end{array}$ & $\begin{array}{l}\text { 95\% Confidence } \\
\text { interval }^{\mathrm{b}}\end{array}$ & $\begin{array}{l}\text { Design } \\
\text { effect }^{c}\end{array}$ \\
\hline \multicolumn{6}{|l|}{ HEV serology } \\
\hline Individual pig-level & 6565 & 1069 & 31 & $24-38$ & 12.4 \\
\hline Farm level & 186 & 137 & 65 & $57-74$ & 1.2 \\
\hline \multicolumn{6}{|l|}{ HEV virology (livers) } \\
\hline Individual pig-level & 3715 & 128 & 4 & $2-6$ & 9.1 \\
\hline Farm level & 186 & 43 & 24 & $17-31$ & 1.4 \\
\hline
\end{tabular}

a Based on sample design, applies to the target population.

b Based on variance estimate using the Taylor series expansion method.

c Ratio of the actual variance (estimated based on the sample design) to the variance of a simple random sample with the same number of observations. 


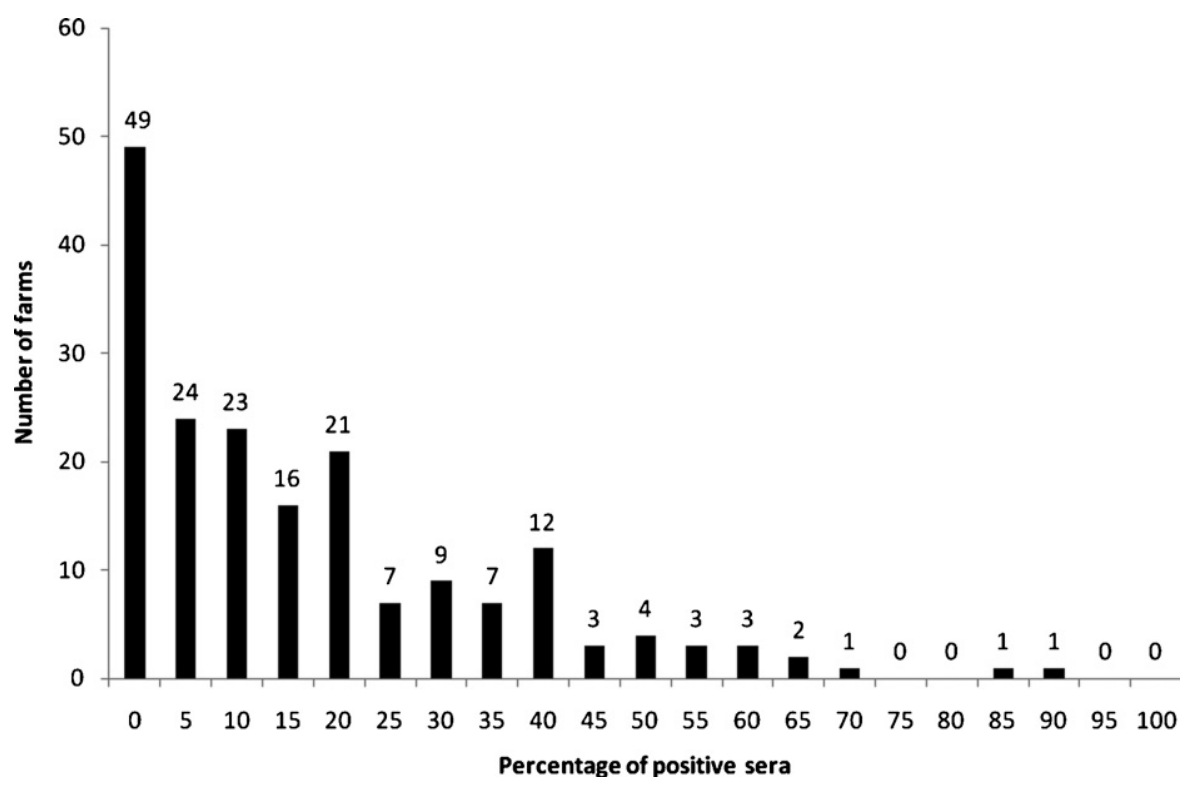

Fig. 1. Distribution of the observed within-farm seroprevalence (186 farms, 2008-2009, France). Chart representing the number of farms ( $Y$ axis) based on the percentage of positive sera per farm $(X$ axis).

\section{Results}

\subsection{HEV seroprevalence}

Taking the sampling design and sensitivity and specificity of the serological test into account, the farm-level seroprevalence was $65 \%$ with [57-74] as $95 \%$ confidence interval and $30 \%$ of the individual slaughter-aged pigs on average had antibodies against HEV (Table 1). The observed within-farm seroprevalence ranged from $3 \%$ to $88 \%$ (median at $10 \%$, Fig. 1). Five regions were defined according to the location of the sampled farms (Fig. 2). More than $60 \%$ of the national pig production comes from western France (North-West + Center-West). When different parameters such as the geographical region of origin, season and farm type were considered, a significant regional effect was only found at the farm level $(p=0.03)$, farms located in western France, the main French pig producing area, being more likely to be seropositive $(\mathrm{OR}=2.4[1-5])$ (Table 2). The effects of season and farm type were nonsignificant ( $p=0.28$ and $p=0.51$, respectively).

\subsection{HEV prevalence in livers}

Among the 3715 livers sampled at the slaughterhouse, 128 were found positive for HEV RNA (Fig. A1). When the sampling design, clustering and unequal weighting of observations were taken into account, the estimated individual prevalence was $4 \%$ with [2-6] as $95 \%$ confidence interval (Table 1). A significant regional effect was found, the North-West area being more at risk than other regions (Table 2). This effect was more pronounced when the western areas (North-West + Center-West) were combined and compared with the other areas $(\mathrm{OR}=3.9$ [1,5-11]). No seasonal effect was found $(p=0.96)$ and the type of farm (farrow-to-finish versus finishing farm) was also nonsignificant $(p=0.09)$ (Table 2$)$.

Prevalence estimates at the farm-level were obtained by considering that the farm was positive if at least 1 liver tested positive. Forty three of the 186 sampled farms had at least $1 \mathrm{HEV}$ positive sample, leading to an estimated farm-level prevalence of $24 \%$ with [17-31] as $95 \%$ confidence interval and taking into account the sampling design, clustering and unequal weighting (Table 1). The observed within-farm prevalence ranged from 5 to $75 \%$ with an extremely left-skewed distribution (Fig. 3). The probability of a farm having at least $1 \mathrm{HEV}$ positive pig was greater in the western area (North-West + Center-West) than in the rest of France $(\mathrm{OR}=3.7[2,7,9])$, and in finishing farms compared with farrow-to-finish farms (OR=2.6 [1-6]). In agreement with individual prevalence findings, the effect of season was non-significant $(p=0.86)$ (Table 2$)$. A strong relationship was observed between the probability that a liver would be HEV positive and within-farm seroprevalence. The odds of a liver being contaminated were almost 7 times higher when the within-farm seroprevalence was greater than $25 \%$ (Table 2). At the individual level, $6.6 \%$ of the livers were detected HEV positive in seropositive animals versus $2.6 \%$ in seronegative pigs.

Sequencing of the PCR products, to characterize the viral strain circulating in the pig reservoir, revealed that all viral strains identified in the liver samples belonged to genotype 3 and more particularly to subtypes $3 e, 3 c$ and $3 f$. Most were of genotype 3f, 76.7\% (33/43) while 3c was identified in $18.6 \%(8 / 43)$ of the liver samples and $3 e$ in $4.6 \%(2 / 43)$. $75.8 \%$ of genotype $3 \mathrm{f}(n=33)$ came from herds located in the North-West (mainly Brittany) whereas 3c genotypes were more frequently found in the South-West and North-East $(62.5 \%, n=8)$.

To confirm that the amplification of viral RNA in the liver samples was correlated with the presence of 


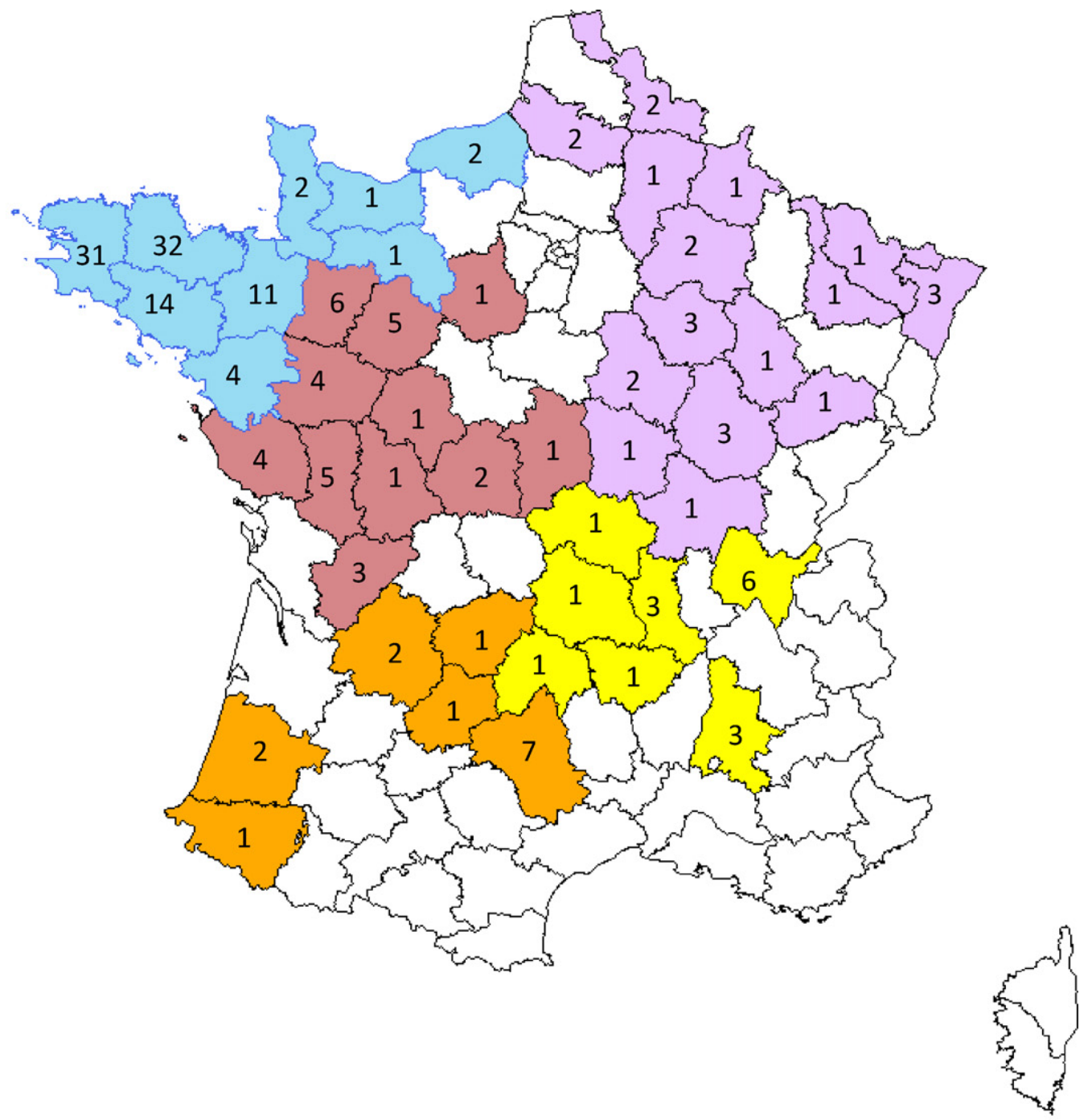

\section{Definition of Regions

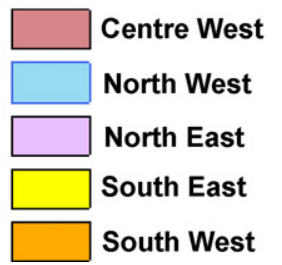

Fig. 2. Definition of regions according to the location of sampled farms and number of tested farms per county (186 sampled farms, 2008-2009, France).

infectious HEV particles, one positive liver sample was used in an experimental model of pig infection. Pigs inoculated intravenously with this liver sample started to shed HEV in their feces 2 days after infection (data not shown) and seroconversion was also observed 31 days post-inoculation (data not shown), thus confirming HEV infection.

The presence of HEV RNA in the serum samples corresponding to positive liver samples was then examined to evaluate if the presence of HEV RNA was concomitant with viremia and possible virus dissemination in the whole organism. HEV RNA was amplified in 17 of the 128 sera (21.1\%) corresponding to pigs with an HEV positive liver.

\section{Discussion}

An accurate quantitative assessment of the role of pigs as potential HEV reservoirs is lacking although several figures have been reported for different countries in the 
Table 2

Factors affecting HEV seroprevalence and prevalence in livers (186 farms, 6565 blood samples, 3715 livers, France, 2008-2009).

\begin{tabular}{|c|c|c|c|c|c|c|c|c|}
\hline \multirow{3}{*}{$\begin{array}{l}\text { Outcome variable and } \\
\text { categories }\end{array}$} & \multicolumn{4}{|l|}{ HEV serology } & \multicolumn{4}{|c|}{ HEV virology (livers) } \\
\hline & \multicolumn{2}{|c|}{ Individual pig-level } & \multicolumn{2}{|l|}{ Farm-level } & \multicolumn{2}{|c|}{ Individual pig-level } & \multicolumn{2}{|l|}{ Farm-level } \\
\hline & OR $(95 \% C I)^{a}$ & $p$ value & OR $(95 \% \mathrm{CI})$ & $p$ value & OR $(95 \% \mathrm{CI})$ & $p$ value & OR $(95 \% \mathrm{CI})$ & $p$ value \\
\hline Region & & 0.22 & & 0.03 & & 0.001 & & 0.06 \\
\hline North-West & $0.8(0.4-1.4)$ & & $0.7(0.1-4.8)$ & & $4.4(1.2-15.9)$ & & $2.0(0.5-7.8)$ & \\
\hline Center-West & $0.7(0.3-1.7)$ & & $0.4(0.05-2.9)$ & & $2.6(0.5-14.2)$ & & $1.0(0.2-5.9)$ & \\
\hline North-East & $0.5(0.2-0.9)$ & & $0.2(0.02-1.2)$ & & $0.4(0.08-1.8)$ & & $0.4(0.07-1.9)$ & \\
\hline South-East & $0.5(0.2-1.6)$ & & $0.3(0.02-4.2)$ & & $3.1(0.6-17.1)$ & & $1.2(0.2-7.6)$ & \\
\hline South-West & 1 & & 1 & & 1 & & 1 & \\
\hline Area of production & & 0.72 & & 0.03 & & 0.01 & & 0.003 \\
\hline Western France & $1.1(0.6-2.1)$ & & $2.4(1.1-5.4)$ & & $3.9(1.4-11.0)$ & & $3.7(1.6-8.7)$ & \\
\hline Other & 1 & & 1 & & 1 & & & \\
\hline Season & & 0.34 & & 0.28 & & 0.96 & & 0.86 \\
\hline Summer & $0.8(0.5-1.4)$ & & $0.4(0.1-1.1)$ & & $1.0(0.3-3.2)$ & & $1.1(0.4-3.3)$ & \\
\hline Autumn & $1.1(0.7-1.9)$ & & $0.7(0.2-1.7)$ & & $1.2(0.3-5.2)$ & & $0.8(0.3-2.1)$ & \\
\hline Winter & $1.5(0.8-3.0)$ & & $0.8(0.2-2.9)$ & & $1.4(0.4-4.9)$ & & $1.2(0.4-3.8)$ & \\
\hline Spring & 1 & & & & 1 & & 1 & \\
\hline Farm type & & 0.37 & & 0.51 & & 0.09 & & 0.03 \\
\hline Finishing & $1.3(0.7-2.2)$ & & $1.4(0.5-3.7)$ & & $2.3(0.9-5.9)$ & & $2.6(1.1-6.0)$ & \\
\hline Farrow-to-finish & 1 & & 1 & & 1 & & 1 & \\
\hline HEV individual serology & $N A^{b}$ & NA & NA & NA & & 0.01 & NA & NA \\
\hline Positive & & & & & $2.8(1.2-6.2)$ & & & \\
\hline Negative & & & & & 1 & & & \\
\hline $\begin{array}{l}\text { HEV within-farm } \\
\text { seroprevalence (\%) }\end{array}$ & NA & NA & NA & NA & & 0.006 & & 0.07 \\
\hline$>25$ & & & & & $6.7(2.1-21.6)$ & & $3.7(1.1-12.1)$ & \\
\hline$[0-25]$ & & & & & $3.2(0.9-11.2)$ & & $1.8(0.6-5.3)$ & \\
\hline Negative & & & & & 1 & & 1 & \\
\hline
\end{tabular}

Boldface indicates a significant result.

a Odds ratio and (95\% confidence interval).

b Not applicable.

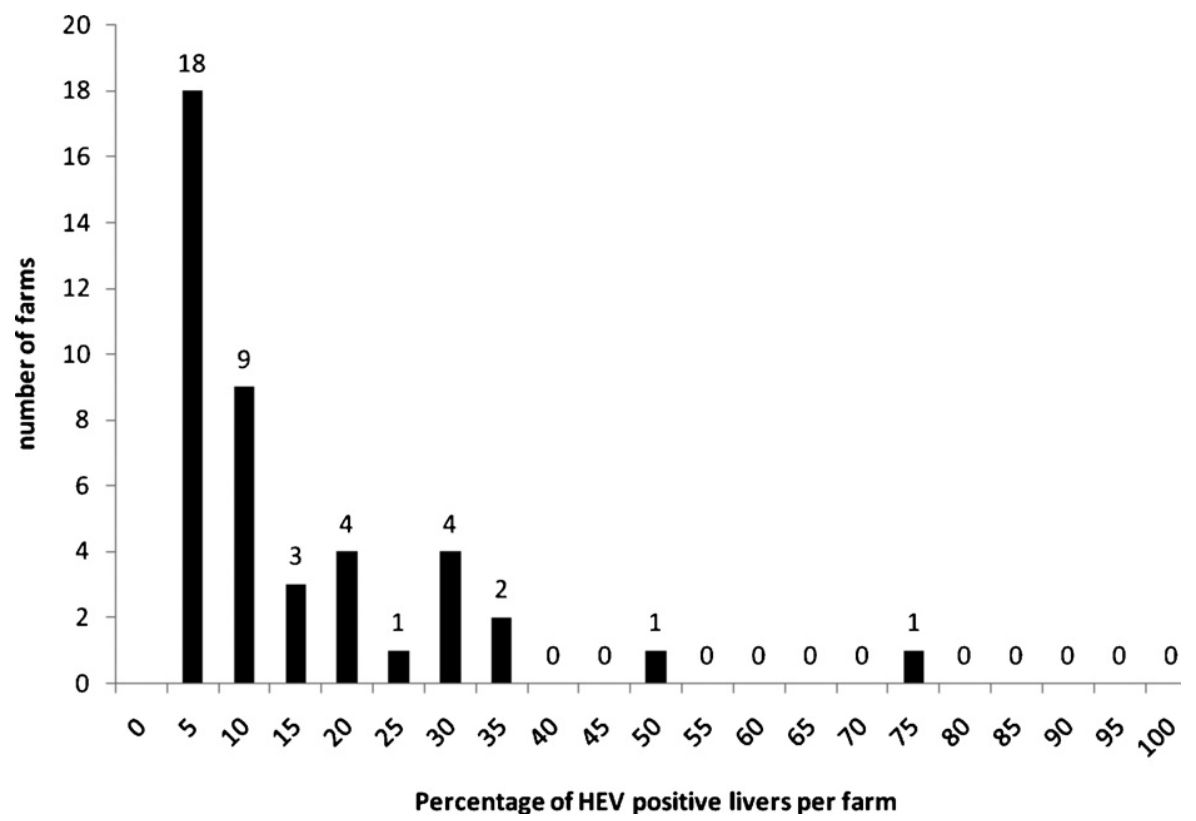

Fig. 3. Distribution of the observed within-farm prevalence of HEV contaminated livers (43 HEV positive farms, 2008-2009, France). Chart representing the number of farms ( $Y$ axis) based on the percentage of positive livers within each farm ( $X$ axis). 
literature. In most of those studies both the sampling strategy and estimates precision were poor because "convenient" samples were taken, in general, and from a limited number of farms and animals [24,25,36-38]. To the best of our knowledge, the present results are the first available from a representative nationwide survey in which HEV antibodies and virus were explored simultaneously in livers from slaughter-aged pigs. In view of the complex sampling design, the obtained prevalence estimates are applicable to the target population. This is of considerable interest when conducting a quantitative risk assessment to estimate the number of HEV cases in humans that can be attributed to the consumption of pork-derived food products.

The main risk for public health consists of delivering pigs to the slaughterhouse which either harbour the virus in different organs such as gall bladder, intestine or muscles or are viremic as previously shown in experimental HEV infection of pigs or at slaughterhouse [39,40]. Positive HEV livers were found in seropositive pigs (6.6\%) but also in seronegative animals (2.6\%), which suggests that positive and negative serological results could not exclude the presence of the virus in slaughter-aged pigs in the case of recent infection [39,41]. One interesting finding from our study is the positive association between the probability of livers being HEV positive and the withinherd HEV seroprevalence. This clearly suggests that specific on-farm conditions favor virus spread and increase the likelihood of delivering infected slaughter-aged pigs. Pigs from finishing farms were more likely to be HEV positive than those from farrow-to-finish farms, which suggests that characteristics related to this rearing system (such as the possible mingling of pigs of different origins) could be a potential risk factor. This suggests that one way of controlling the overall level of HEV infection in the pig reservoir would be to develop a rearing management plan.

The observed frequencies of HEV positive livers in other countries (The Netherlands [25] or USA [24]) were higher than the observed prevalence in our study. In the study performed in the USA, the same detection method was used, thus, this difference could be explained by the sampling strategy as well as the different farming systems in such countries, the farrow-to-finish system being dominant in France and the wean-to-finish or finishing systems with collective farrowing units being the main systems encountered in The Netherlands and USA. The presence of HEV RNA in serum samples also suggests that the consumption of pig organs other than liver (e.g. muscles) might constitute a risk. Many pork-derived food products are consumed after a brief drying process (dry ham) that may not inactivate HEV. Investigation of HEV presence in other pig organs should be considered as well as the impact of processes on $\mathrm{HEV}$ inactivation.

The regional effect showed that the probability of obtaining HEV positive livers was higher in western France, which is this country's main production area. This observation is in contradiction to the observed distribution of human cases in France (mostly located in the South-East and South-West [15]). However, pigs from western France are exported and processed all over the country. In contrast to the eating habits in northern France, there is a strong tradition specific to the South France for food products based on raw pork liver. These products (Figatelli, smoked liver sausage, dried liver sausage) are manufactured, sold and consumed locally [10].

In France, the non-imported Hepatitis E are mainly due to subtypes $3 f$ (up to $88 \%$ ), $3 c$ and 3e [42,43], the latter two also being the dominant subtypes in pigs in many European countries [44]. HEV detection in pig liver sausages showed a majority of $3 \mathrm{f}$, followed by the $3 \mathrm{c}$ and $3 \mathrm{e}$ subtypes [10], which is in line with our findings in livers taken from slaughter-aged pigs ( $3 \mathrm{f}=76.7 \%$ ). Evidence of foodborne infections through consumption of raw liver-based sausages [10] or undercooked offal [45] as well as high seroprevalence in professionals exposed to pigs [26,27], all suggest a potential involvement of the pig population in the epidemiology of human HEV infections. Furthermore, both the high prevalence in the domestic pig population and the similar distribution of genotypes in autochthonous human cases suggest a high potential for zoonotic transmission. Given the wide spread of the virus in the pig population and the amount of pork products consumed in France, one would expect many more cases than have been observed. Viral hepatitis E is very likely underdiagnosed since the HEV seroprovalence in French blood donors is high (3.2-16.4\% depending on the area). Further data are needed as regards the infectious doses and the effect of food product processing and cooking on survival of the virus in pork-derived products.

\section{Conflict of interest statement}

The authors declare that they have no competing interests.

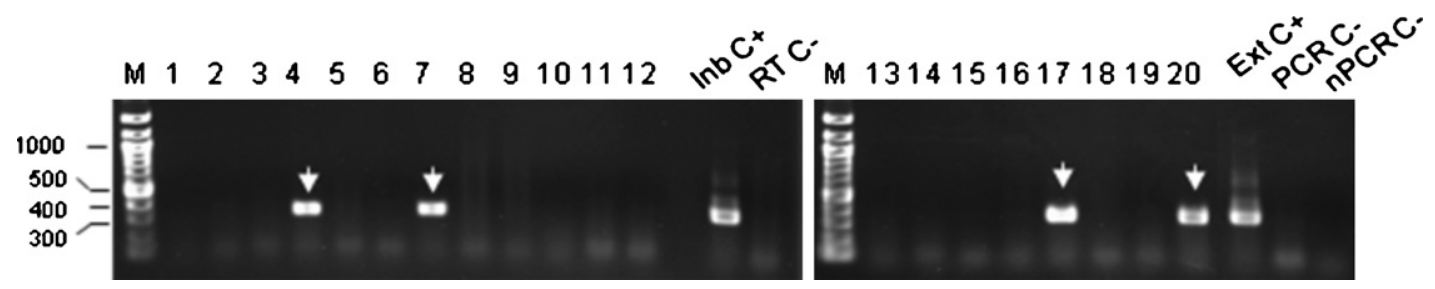

Fig. A1. Detection by RT-nested PCR of partial ORF-2 of HEV in liver samples from one selected herd. Liver samples are numbered 1-20. Positive samples (fragment of 348 base pair) are indicated with a white arrow. Inb C+: control for testing the absence of inhibitor. ExtC+: positive liver extracted and analyzed simultaneously. RTC-, PCR C- and NPCRC- are respectively negative control of the RT, first- and nested PCR. M: molecular weight marker, size are indicated on the left in base pair. 


\section{Acknowledgements}

This study was supported by a national grant from Agence Nationale de la Recherche (PNRA07-008 HEVEZOONEPI). AL was supported by this grant for 24 months (PNRA07-008 HEVEZOONEPI).

\section{Appendix A.}

See Fig. A1.

\section{References}

[1] Emerson SU, Anderson D, Arankalle A, Meng XJ, Purdy M, Schlauder GG, Tsarev SA. Genus hepevirus. In: Fauquet CM, Mayo MA, Maniloff J, Desselberger U, Ball LA, editors. Virus taxonomy: eighth report of the International Committee on Taxonomy of Viruses. London: Elsevier/Acandemic Press; 2004. p. 853-7.

[2] Jameel S. Molecular biology and pathogenesis of hepatitis E virus. Exp Rev Mol Med 1999;1:1-16.

[3] Purcell RH, Emerson SU. Hepatitis E virus. In: Knipe D, Howe P, editors. Fields virology. New York: Raven press; 2001. p. 3051-61.

[4] Gerolami R, Moal V, Colson P. Chronic hepatitis E with cirrhosis in a kidney-transplant recipient. N Engl J Med 2008;358:859-60.

[5] Kamar N, Selves J, Mansuy JM, Ouezzani L, Péron JM, Guitard J, Cointault O, Esposito L, Abravanel F, Danjoux M, Durand D, Vinel JP, Izopet J, Rostaing L. Hepatitis E virus and chronic hepatitis in organtransplant recipients. N Engl J Med 2008;358(8):811-7.

[6] Nicand E, Bigaillon C, Tessé S. Hepatitis E in France: surveillance data for human cases, 2006-2008. Bull Epidémiol Hebd 2009;3(1-32):337-42.

[7] Nicand E, Delaune C, Tessé S. Données de surveillance des cas humains d'hépatite E en France 2006-2009. Feuill Biol 2011;298:19-24.

[8] Tei S, Kitajima N, Takahashi K, Mishiro S. Zoonotic transmission of hepatitis $\mathrm{E}$ virus from deer to human beings. Lancet 2003;362(9381):371-3.

[9] Li TC, Chijiwa K, Sera N, Ishibashi T, Etoh Y, Shinohara Y, Kurata Y, Ishida M, Sakamoto S, Takeda N, Miyamura T. Hepatitis E virus transmission from wild boar meat. Emerg Infect Dis 2005;11(12):1958-60.

[10] Colson P, Borentain P, Quyriaux B, Kaba M, Moal V, Gallina P, Heyries L, Raoult D, Gerolami R. Pig liver sausage as a source of Hepatitis E virus transmission to humans. J Infect Dis 2010;202(6):825-34.

[11] Wichmann O, Schimanski S, Koch J, Kohler M, Rothe C, Plentz A, Jilg W, Stark K. Phylogenetic and case-control study on hepatitis E virus infection in Germany. J Infect Dis 2008;198(12):1732-41.

[12] Kuniholm MH, Pureell RH, McQuillan GM, Engle RE, Wasley A, Nelson KE. Epidemiology of hepatitis E virus in the United States: results from the third national health and nutrition examination survey, 1988-1994. J Infect Dis 2009;200(1):48-56.

[13] Mansuy JM, Legrand-Abravanel F, Calot JP, Peron JM, Alric L, Agudo S, Rech H, Destruel F, Izopet J. High prevalence of anti-hepatitis E virus antibodies in blood donors from South West France. J Med Virol 2008;80(2):289-93.

[14] Boutrouille A, Bakkali-Kassimi L, Crucière C, Pavio N. Prevalence of anti-hepatitis E virus antibodies in French blood donors. J Clin Microbiol 2007;45(6):2009-10.

[15] Renou C, Moreau X, Pariente A, Cadranel J-F, Maringe E, Morin T, Causse X, Payen J-L, Izopet J, Nicand E, Bourlière M, Penaranda G, Hardwigsen J, Gerolami R, Peron J-M, Pavio N. A national survey of acute hepatitis E in France. Aliment Pharmacol Ther 2008;27(11):1086-93.

[16] Blacksell SD, Myint KSA, Khounsy S, Phruaravanh M, Mammen Jr MP, Day NPJ, Newton PN. Prevalence of hepatitis E virus antibodies in pigs: implications for human infections in village-based subsistence pig farming in the Lao PDR. Trans R Soc Trop Med Hyg 2007; 101(3):305-7.

[17] Cooper K, Huang FF, Batista L, Rayo CD, Bezanilla JC, Toth TE, Meng $\mathrm{XJ}$. Identification of genotype 3 hepatitis $\mathrm{E}$ virus (HEV) in serum and fecal samples from pigs in Thailand and Mexico, where genotype 1 and $2 \mathrm{HEV}$ strains are prevalent in the respective human populations. J Clin Microbiol 2005:43(4):1684-8.

[18] Garkavenko O, Obriadina A, Meng J, Anderson DA, Benard HJ, Schroeder BA, Khudyakov YE, Fields HA, Croxson MC. Detection and characterisation of swine hepatitis E virus in New Zealand. J Med Virol 2001;65(3):525-9.

[19] Meng X-J, Purcell RH, Halbur PG, Lehman JR, Webb DM, Tsareva TS, Haynes JS, Thacker BJ, Emerson SU. A novel virus in swine is closely related to the human hepatitis E virus. Proc Natl Acad Sci USA 1997;94(18):9860-5.

[20] Seminati C, Mateu E, Peralta B, de Deus N, Martin M. Distribution of hepatitis $\mathrm{E}$ virus infection and its prevalence in pigs on commercial farms in Spain. Vet J 2008;175(1):130-2.

[21] Guimaraes FR, Saddi TM, Vitral CL, Pinto MA, Gaspar AMC, Souto FJD. Hepatitis E virus antibodies in swine herds of Mato Grosso State, Central Brazil. Braz J Microbiol 2005;36(3):223-6.

[22] Munne MS, Vladimirsky S, Otegui L, Castro R, Brajterman L, Soto S, Guarnera E, Molina V, Monfellano M, Schlauder GG, Gonzalez $\mathrm{JE}$. Identification of the first strain of swine hepatitis $\mathrm{E}$ virus in South America and prevalence of anti-HEV antibodies in swine in Argentina. J Med Virol 2006;78(12):1579-83.

[23] Takahashi M, Nishizawa T, Miyajima H, Gotanda Y, Lita T, Tsuda F, Okamoto $\mathrm{H}$. Swine hepatitis E virus strains in Japan form four phylogenetic clusters comparable with those of Japanese isolates of human hepatitis E virus. J Gen Virol 2003:84(4):851-62.

[24] Feagins AR, Opriessnig T, Guenette DK, Halbur PG, Meng X-J. Detection and characterization of infectious Hepatitis $\mathrm{E}$ virus from commercial pig livers sold in local grocery in the USA. J Gen Virol 2007;88(3):912-7.

[25] Bouwknegt M, Lodder-Verschoor F, Van Der Poel WHM, Rutjes SA. Human AMDR Hepatitis E virus RNA in commercial porcine livers in The Netherlands. J Food Prot 2007;70(12):2889-95.

[26] Meng XJ, Wiseman B, Elvinger F, Guenette DK, Toth TE, Engle RE, Emerson SU, Purcell RH. Prevalence of antibodies to hepatitis virus in veterinarians working with swine and in normal blood donors in the United States and other countries. J Clin Microbiol 2002;40(1):117-22.

[27] Olsen B, Axelsson-Olsson D, Thelin A, Weiland O. Unexpected high prevalence of IgG-antibodies to hepatitis E virus in Swedish pig farmers and controls. Scand J Infect Dis 2006;38(1):55-8.

[28] Rose N, Boutrouille A, Fablet C, Madec F, Eloit M, Pavio N. The use of Bayesian methods for evaluating the performance of a virus-like particles-based ELISA for serology of hepatitis $\mathrm{E}$ virus infection in swine. J Virol Methods 2010;163(2):329-35.

[29] Cariolet R, Le Diguerher G, Ecobichon P, Julou P, Jolly JP, Madec F. Production of long term, low-cost specific pathogen free pigs. In ISPAIA, editor. Symposium of the International Society for Animal Hygiene; 2004 October 11-13. 2004. p. 149

[30] Bouquet J, Tessé S, Lunazzi A, Eloit M, Rose N, Nicand E, Pavio N. Close similarity between sequences of Hepatitis E Virus recovered from Human and Swine in France between 2008 and 2009. Emerg Infect Dis 2011, in press.

[31] Jothikumar N, Cromeans TL, Robertson BH, Meng XJ, Hill VR. A broadly reactive one-step real-time RT-PCR assay for rapid and sensitive detection of hepatitis E virus. J Virol Methods 2006 Jan;131(1):65-71.

[32] SAS Institute Inc. SAS/STAT User's Guide. Cary, NC, USA: SAS Institute; 2002.

[33] Fuller WA. Regression analysis for sample survey. Sankhy 1975;37:117-32 [Series C(3)].

[34] Woodruff RS. A simple method for approximating the variance of a complicated estimate. J Am Stat Assoc 1971;66:411-4.

[35] Dohoo I, Martin W, Stryhn H. Veterinary Epidemiologic Research. Charlottetown, Prince Edward Island, Canada: AVC Inc.; 2003.

[36] Di Bartolo I, Martelli F, Inglese N, Pourshaban M, Caprioli A, Ostanello F, Ruggeri FM. Widespread diffusion of genotype 3 hepatitis E virus among farming swine in Northern Italy. Vet Microbiol 2008:132(1-2):47-55.

[37] Breum SO, Hjulsager CK, de Deus N, Segalés J, Larsen LE. Hepatitis E virus is highly prevalent in the Danish pig population. Vet Microbiol 2010.

[38] Di Bartolo I, Ponterio E, Castellini L, Ostanello F, Ruggeri FM. Viral and antibody HEV prevalence in swine at slaughterhouse in Italy. Vet Microbiol 2011;149:3-4, 330-8.

[39] Bouwknegt M, Rutjes SA, Reusken CB, Stockhofe-Zurwieden N, Frankena K, de Jong MC, de Roda Husman AM, Poel WH. The course of hepatitis $\mathrm{E}$ virus infection in pigs after contact-infection and intravenous inoculation. BMC Vet Res 2009;5(7).

[40] Leblanc D, Poitras E, Gagné MJ, Ward P, Houde A. Hepatitis E virus load in swine organs and tissues at slaughterhouse determined by real-time RT-PCR. Int J Food Microbiol 2010;139(3):206-9.

[41] Kanai Y, Tsujikawa M, Yunoki M, Nishiyama S, Ikuta K, Hagiwara K. Long-term shedding of hepatitis $\mathrm{E}$ virus in the feces of pigs infected 
naturally, born to sows with and without maternal antibodies. J Med Virol 2011;82(1):69-76.

[42] Legrand-Abravanel F, Kamar N, Sandres-Saune K, Garrouste C, Dubois M, Mansuy JM, Muscari F, Sallusto F, Rostaing L, Izopet J. Characteristics of autochthonous hepatitis $\mathrm{E}$ virus infection in solid-organ transplant recipients in France. J Infect Dis 2010;202(6):835-44.

[43] Legrand-Abravanel F, Mansuy J-M, Dubois M, Kamar N, Peron J-M, Rostaing L, Izopet J, Hepatitis. E virus genotype 3 diversity, France. Emerg Infect Dis 2009;15(1):110-4.
[44] Lu L, Li C, Hagedorn CH. Phylogenetic analysis of global hepatitis E virus sequences: genetic diversity, subtypes and zoonosis. Rev Med Virol 2006;16(1):5-36.

[45] Yazaki Y, Mizuo H, Takahashi M, Nishizawa T, Sasaki N, Gotanda Y, Okamoto H. Sporadic acute or fulminant hepatitis E in Hokkaido, Japan, may be food-borne, as suggested by the presence of hepatitis E virus in pig liver as food. J Gen Virol 2003;84(9): 2351-7. 